\title{
PENGARUH MODEL PEMBELAJARAN PROBING-PROMPTING TERHADAP HASIL BELAJAR IPS DENGAN KOVARIABEL MOTIVASI BERPRESTASI PADA SISWA KELAS IV DI SD GUGUS VI KECAMATAN BULELENG
}

\author{
I Made Bagus Susila Putra
}

SD Negeri 6 Dauhwaru, Kabupaten Jembrana

bagussusila9@gmail.com

\section{INFO ARTIKEL}

\section{Riwayat Artikel:}

Diterima:11-Januari-2021

Disetujui:21-September-2021

\section{Kata Kunci:}

Probing-Prompting, hasil belajar IPS, motivasi berprestasi

\section{ABSTRAK}

\begin{abstract}
Abstrak: Penelitian ini bertujuan untuk menganalisis perbedaan hasil belajar IPS antara kelompok siswa yang dibelajarkan dengan model pembelajaran Probing-Prompting dan kelompok siswa yang dibelajarkan dengan model pembelajaran konvensional dengan dilakukan kontrol terhadap kovariabel motivasi berprestasi pada siswa kelas IV di SD Gugus VI Kecamatan Buleleng. Sampel penelitian yaitu kelas IV SDN 1 berjumlah 23 siswa dan kelas IV SDN 2 berjumlah 22 siswa. Data skor hasil belajar dikumpulkan dengan instrumen tes pilihan ganda dan data skor motivasi berprestasi dikumpulkan dengan instrument kuesioner. Data yang dikumpulkan dianalisis menggunakan analisis statistik deskriptif dan statistik inferensial (uji ANAVA, uji ANAKOVA, dan uji korelasi Product Moment). Hasil penelitian menunjukkan bahwa rata-rata skor hasil belajar IPS kelompok eksperimen adalah 14,50 lebih besar dari rata-rata skor hasil belajar IPS kelompok kontrol adalah sebesar 9,56. Ketiga hipotesis penelitian diuji dengan taraf signifikansi 5\%. Sebelum dilakukan kontrol terhadap motivasi berprestasi didapatkan $F_{\text {hitung }}=29,062$. Kemudian, setelah motivasi berprestasi dikontrol didapatkan $F_{\text {hitung }}=14,703$ dan korelasi antara motivasi berprestasi dan hasil belajar IPS dengan thitung $=9,670$. Hal ini membuktikan bahwa, tetap terdapat perbedaan hasil belajar IPS antara kelompok siswa yang dibelajarkan dengan model pembelajaran Probing-Prompting dan kelompok siswa yang dibelajarkan dengan model pembelajaran konvensional setelah motivasi berprestasi dikontrol.
\end{abstract}

Abstract:

\section{A. LATAR BELAKANG}

Tujuan hidup pada hakikatnya adalah untuk tetap hidup dengan cara menghidupi orang lain. Dikatakan menghidupi orang lain karena secara perspektif sosial, setiap manusia yang menempuh kehidupan pada akhirnya akan menjadi pribadi yang menerapkan keterampilannya. Terjadi kesenjangan infrastruktur sekolah di kota dengan sekolah di desa. Kemudian, Indonesia merupakan negara dengan keberagaman budaya dan etnis. Keberagaman tersebut berdampak juga bagi kualitas kemampuan penerimaan materi ajar.

Kemampuan peserta didik di daerah kota berbeda dengan di daerah terpencil. Kedua kendala tersebut menghambat peningkatan kualitas pendidikan di Indonesia. Dewasa ini, pemerintah telah melakukan upaya untuk mengatasi kendala tersebut dengan adanya perubahan kebijakan pendidikan. Salah satu mata pelajaran yang berperan dalam pengembangan potensi peserta didik adalah mata pelajaran IPS (Ilmu Pengetahuan Sosial).

Ilmu Pengetahuan Sosial (IPS) merupakan suatu program pendidikan yang mengintegrasikan konsepkonsep ilmu sosial dan humaniora untuk tujuan pendidikan (Lasmawan, 2010). IPS kalau ditinjau dari kerangka kerjanya adalah bukan akademis melainkan praktis, terutama dalam memandang masalah sosial di masyarakat, ilmu pengetahuan sosial diajarkan dari tingkat sekolah dasar sampai di perguruan tinggi dan IPS berinduk kepada ilmu-ilmu sosial yang ada (Murda dan Syahrudin, 2000). IPS adalah ilmu pengetahuan yang mengkaji berbagai disiplin ilmu sosial dan humaniora serta kegiatan dasar manusia yang dikemas secara ilmiah dalam rangka memberi wawasan dan pemahaman yang mendalam kepada peserta didik, khususnya di tingkat dasar dan menengah (Susanto, 2013). Berdasarkan pengertian tersebut dapat dipahami bahwa IPS kajiannya sangat luas dan ajarkan kepada peserta didik sesuai jenjang pendidikan. Pendidikan IPS di sekolah dasar mempunyai peran yang sangat penting untuk membentuk dan mengembangkan potensi diri peserta didik. Selain mengembangkan potensi peserta didik, pendidikan IPS menjadi peletak dasar kemampuan peserta didik dalam memahami situasi sosial mereka. Dari berbagai upaya yang dilakukan pemerintah tersebut, harapan pemerintah untuk memajukan 
kualitas pendidikan secara merata di Indonesia masih belum tercapai. Kemajuan kualitas pendidikan di Indonesia belum menunjukkan hasil yang memuaskan di berbagai daerah.

Hasil observasi menunjukkan bahwa keterampilan guru kelas IV di Gugus VI Kecamatan Buleleng, Kabupaten Buleleng dalam mengembangkan model pembelajaran di kelas masih belum optimal. Dalam mengajar di kelas, guru cenderung menyampaikan metode ceramah secara penuh, siswa hanya sebagai pendengar dan pencatat. Setelah melakukan metode ceramah, guru melakukan metode tanya jawab ke beberapa siswa. Tanya jawab dilakukan secara tidak merata dan mendalam. Ini menyebabkan siswa kurang berpartisipasi aktif dalam pembelajaran. Kemudian, guru memberikan sedikit waktu bagi siswa untuk berdiskusi dengan siswa lain untuk mengerjakan tugas sebagai evaluasi hasil belajar. Pembelajaran seperti itu dikenal dengan model pembelajaran konvensional. Pembelajaran konvensional yang menekankan metode ceramah dan pemberian tugas dapat menyebabkan kurangnya kemampuan peserta didik dalam mengeksplorasi materi pelajaran secara mandiri.

Terkait temuan di lapangan, maka salah satu cara yang dapat dilakukan oleh guru adalah memilih model pembelajaran Probing-Prompting. Model pembelajaran Probing-Prompting adalah suatu model dengan cara guru menyajikan serangkaian pertanyaan yang sifatnya menuntun dan menggali, sehingga terjadi proses berpikir yang mengaitkan pengetahuan siswa dan pengalamannya dengan pengetahuan baru yang sedang dipelajar (Suyatno, 2009). Prompting question dapat digunakan sebagai teknik untuk meningkatkan kualitas dan kuantitas jawaban siswa, dengan kata lain prompting merupakan cara lain dalam merespon atau menanggapi jawaban siswa apabila siswa gagal menjawab pertanyaan, atau jawaban siswa kurang sempurna (Swarjawa, 2013). Dengan model pembelajaran Probing-Prompting, proses tanya jawab dilakukan dengan menunjuk siswa secara acak sehingga setiap siswa mau tidak mau harus berpartisipasi aktif (Shoimin, 2014). Model pembelajaran Probing-Prompting memiliki tujuh fase (sintaks) dalam pembelajaran: 1) Situasi Baru (New Situation); 2) Kesempatan Berpikir (Think Opening); 3) Persoalan (Questions); 4) Kesempatan Berpikir (Think Opening); 5) Menjawab Pertanyaan (Reply the Questions); 6) Menguji Pemahaman (Screen Comprehension); 7) Pertanyaan Akhir (Last Questions) (dimodifikasi dari Shoimin, 2014).

\section{B. METODE PENELITIAN}

Jenis penelitian ini adalah penelitian eksperimen semu (quasi experiment). Disebut quasi eksperiment atau penelitian semu karena memiliki kelompok kontrol dan tidak semua variabel-variabel luar yang memengaruhi pelaksanaan eksperimen dapat dikontrol secara ketat (Sugiyono, 2010). Penelitian ini menggunakan desain penelitian Non-Equivalen Posttest-Only Control Design. Desain penelitian tersebut disajikan dalam gambar 1 sebagai berikut:

\begin{tabular}{c|c|c}
\hline $\mathrm{E}$ & $\mathrm{X}$ & $\mathrm{O} 1$ \\
$\mathrm{~K}$ & - & $\mathrm{O} 2$ \\
\hline \multicolumn{2}{c}{ (Sugiyono, 2010) }
\end{tabular}

Kelas yang dijadikan sampel penelitian adalah kelas IV SD di Gugus VI Kecamatan Buleleng, Kabupaten Buleleng. Metode pengambilan sampel yang digunakan dalam penelitian ini adalah metode random sampling. Prosedur penelitian ini meliputi tahapan-tahapan yang dilakukan dalam melakukan penelitian. Penelitian ini terdiri dari dua tahap penelitian yaitu tahap persiapan eksperimen dan tahap pelaksanaan eksperimen.

Metode pengumpulan data yang digunakan pada penelitian ini adalah metode tes dan kuesioner. Data hasil belajar IPS dikumpulkan dengan menggunakan instrumen tes pilihan ganda sebanyak 30 butir. Data motivasi berprestasi dikumpulkan dengan menggunakan kuesioner sebanyak 20 butir. Skala pengukuran data dalam penelitian adalah skala interval yang bercirikan mempunyai perbedaan, jenjang atau tingkatan, dan jarak yang pasti. Skala interval data yang dimaksud dalam penelitian berbentuk skor hasil belajar IPS dan skor motivasi berprestasi siswa (Agung, 2010). Uji coba instrumen penelitian dilakukan untuk mendapat gambaran secara empiris apakah seluruh instrumen layak digunakan sebagai instrumen penelitian. Instrumen yang digunakan dalam penelitian ini terlebih dahulu dilakukan penilaian pakar (judges) sebelum ditetapkan sebagai instrumen penelitian, selanjutnya dilakukan uji coba dengan tujuan untuk mengetahui tingkat validitas, tingkat kesukaran tes, daya beda tes dan tingkat reliabilitas tes. Validitas Instrumen Tes Hasil Belajardan Validitas dan Reliabilitas Kuesioner Motivasi Berprestasi (Candiasa, 2010).

Teknik analisis statistik inferensial yang digunakan adalah untuk pengujian ketiga hipotesis yang meliputi uji perbedaan ANAVA satu jalur, uji ANAKOVA satu jalur, dan teknik analisis regresi sederhana menggunakan korelasi product moment. Sebelum melakukan ketiga uji hipotesis tersebut, terlebih dahulu dilakukan analisis uji prasyarat yang meliputi uji normalitas sebaran data, uji homogenitas varians, uji linieritas regresi. Analisis 
statistik yang digunakan untuk menguji hipotesis penelitian pertama analisis uji ANAVA satu jalur, yang kedua dengan ANAKOVA satu jalur, dan hipotesis ketiga dengan korelasi product moment (Candiasa, 2010).

\section{HASIL DAN PEMBAHASAN \\ Hasil Penelitian}

Data yang diperoleh dalam penelitian adalah data tentang hasil belajar IPS pada kelompok siswa yang mengikuti pembelajaran dengan model pembelajaran Probing-Prompting (A1) dan kelompok siswa yang mengikuti pembelajaran dengan model pembelajaran konvensional (A2). Rincian data tentang kedua pembelajaran di atas dianalisis dengan statistik deskriptif menggunakan bantuan program SPSS Statistics 17.00. Deskripsi data hasil belajar IPS pada kelompok eksperimen (A1) dan kelompok kontrol (A2) disajikan pada tabel 1 sebagai berikut:

\begin{tabular}{l|c|c}
\hline \multicolumn{1}{c|}{ Data Statistik } & A1 & A2 \\
\hline Mean & 14,50 & 9,56 \\
\hline Median & 14,50 & 10,00 \\
\hline Standar Deviasi (SD) & 2,63 & 3,43 \\
\hline Varians & 6,93 & 11,82 \\
\hline Skor Minimum & 11,00 & 3,00 \\
\hline Skor Maksimum & 20,00 & 17,00 \\
\hline Rentangan & 9,00 & 14,00 \\
\hline
\end{tabular}

Keterangan:

A1 : Hasil belajar IPS siswa kelompok siswa yang dibelajarkan dengan model pembelajaran probingprompting.

A2 : Hasil belajar IPS siswa kelompok siswa yang dibelajarkan dengan model pembelajaran konvensional.

\section{Deskripsi Data Hasil Belajar IPS Kelompok Eksperimen (A1)}

Berdasarkan rekapitulasi hasil perhitungan skor hasil belajar IPS kelompok siswa yang dibelajarkan dengan model pembelajaran Probing-Prompting (A1) yang telah dipaparkan, dapat dibuat tabel kerja untuk menghitung harga-harga statistik M dan SD pada tabel 2 sebagai berikut:

\begin{tabular}{c|c|c|c|c|c|c}
\hline $\begin{array}{c}\text { Kelas } \\
\text { Interval }\end{array}$ & $\begin{array}{c}\text { Titik } \\
\text { Tengah }\end{array}$ & $\mathbf{f}$ & $\begin{array}{c}\mathbf{f} \text { relatif } \\
(\boldsymbol{\%})\end{array}$ & $\mathbf{f X}$ & $\mathbf{X}^{\mathbf{2}}$ & $\mathbf{f X}^{\mathbf{2}}$ \\
\hline $19-20$ & 19,5 & 1 & 4,55 & 19,5 & 380,25 & 380,25 \\
\hline $17-18$ & 17,5 & 5 & 22,73 & 87,5 & 306,25 & 1531,25 \\
\hline $15-16$ & 15,5 & 5 & 22,73 & 77,5 & 240,25 & 1201,25 \\
\hline $13-14$ & 13,5 & 4 & 18,18 & 54 & 182,25 & 729 \\
\hline $11-12$ & 11,5 & 7 & 31,82 & 80,5 & 132,25 & 925,75 \\
\hline \multirow{2}{*}{ Jumlah } & - & 22 & - & 319 & - & 4767,5 \\
\cline { 2 - 6 } & - & $\mathrm{N}$ & - & $\sum \mathrm{fX}$ & - & $\sum \mathrm{fX}^{2}$ \\
\hline
\end{tabular}

Dapat diuraikan bahwa banyaknya siswa yang memiliki skor pada rentangan skor 19-20 dengan nilai tengah 19,5 berjumlah 1 orang siswa dengan frekuensi relatif sebesar 4,55\%. Jumlah siswa yang memiliki rentang skor 1718 dengan nilai tengah 17,5 berjumlah 5 orang siswa dengan frekuensi relatif sebesar 22,73\%. Jumlah siswa yang memiliki rentang skor 15-16 dengan nilai tengah 15,5 berjumlah 5 orang siswa dengan frekuensi relatif sebesar $22,73 \%$. Jumlah siswa yang memiliki rentang skor 13-14 dengan nilai tengah 13,5 berjumlah 4 orang siswa dengan frekuensi relatif sebesar $18,18 \%$. Dan, jumlah siswa yang memiliki rentang skor 11-12 dengan nilai tengah 11,5 berjumlah 7 orang siswa dengan frekuensi relatif sebesar $31,82 \%$.

Kemudian, jika dilihat dari rata-rata (mean) $=14,5$ dan dikonversikan dapat diketahui bahwa kencederungan data hasil belajar IPS kelompok siswa yang mengikuti pembelajaran dengan model pembelajaran ProbingPrompting masuk dalam kategori Cukup. Dengan menentukan nilai ketuntasan mata pelajaran IPS dari sekolah yaitu nilai sebesar 70 atau dengan jumlah skor minimal 14 maka kelompok siswa yang dibelajarkan dengan model pembelajaran Probing-Prompting siswa yang tuntas sebanyak 13 orang dengan frekuensi 59,09\%. 


\section{Deskripsi Data Hasil Belajar IPS Kelompok Kontrol (A2)}

Berdasarkan rekapitulasi hasil perhitungan skor hasil belajar IPS kelompok siswa yang dibelajarkan dengan model pembelajaran konvensional (A2) yang telah dipaparkan, dapat dibuat tabel kerja untuk menghitung hargaharga statistik M dan SD pada tabel 3 sebagai berikut.

\begin{tabular}{c|c|c|c|c|c|c}
\hline $\begin{array}{c}\text { Kelas } \\
\text { Interval }\end{array}$ & $\begin{array}{c}\text { Titik } \\
\text { Tengah }\end{array}$ & $\mathbf{f}$ & $\begin{array}{c}\text { frelatif } \\
(\boldsymbol{\%})\end{array}$ & $\mathbf{f X}$ & $\mathbf{X}^{\mathbf{2}}$ & $\mathbf{f X}^{\mathbf{2}}$ \\
\hline $15-17$ & 16 & 2 & 8,69 & 32 & 256 & 512 \\
\hline $12-14$ & 13 & 4 & 17,39 & 52 & 169 & 676 \\
\hline $9-11$ & 10 & 9 & 39,13 & 90 & 100 & 900 \\
\hline $6-8$ & 7 & 5 & 21,74 & 35 & 49 & 245 \\
\hline $3-5$ & 4 & 3 & 13,04 & 12 & 16 & 48 \\
\hline \multirow{2}{*}{ Jumlah } & - & 23 & - & 221 & - & 2381 \\
\cline { 2 - 7 } & - & $\mathrm{N}$ & - & $\sum \mathrm{fX}$ & - & $\sum \mathrm{fX}^{2}$ \\
\hline
\end{tabular}

Dapat diuraikan bahwa banyaknya siswa yang memiliki skor pada rentangan skor 15-17 dengan nilai tengah 16 berjumlah 2 orang siswa dengan frekuensi relatif sebesar 8,69\%. Jumlah siswa yang memiliki rentang skor 1214 dengan nilai tengah 13 berjumlah 4 orang siswa dengan frekuensi relatif sebesar 17,39\%. Jumlah siswa yang memiliki rentang skor 9-11 dengan nilai tengah 10 berjumlah 9 orang siswa dengan frekuensi relatif sebesar $39,13 \%$. Jumlah siswa yang memiliki rentang skor 6-8 dengan nilai tengah 7 berjumlah 5 orang siswa dengan frekuensi relatif sebesar 21,74\%. Dan, jumlah siswa yang memiliki rentang skor 3-5 dengan nilai tengah 4 berjumlah 3 orang siswa dengan frekuensi relatif sebesar 13,04\%. rata-rata (mean) $=9,61$ dan dikonversikan, dapat diketahui bahwa kencederungan data hasil belajar IPS kelompok siswa yang mengikuti pembelajaran dengan model pembelajaran konvensional masuk dalam kategori Cukup. Dengan menentukan nilai ketuntasan mata pelajaran IPS dari sekolah yaitu nilai sebesar 70 atau dengan jumlah skor minimal 14 maka kelompok siswa yang dibelajarkan dengan model pembelajaran Probing-Prompting siswa yang tuntas sebanyak 3 orang dengan frekuensi $13,04 \%$.

Berdasarkan deskripsi data hasil belajar IPS yang telah diuraikan, didapatkan hasil ketuntasan pada kelompok eksperimen sebesar 59,09\% sedangkan pada kelompok kontrol sebesar 13,04\%. Jadi, frekuensi relatif ketuntasan pada kelas eksperimen > kelas kontrol sebesar 46,05\%.

\section{Hasil Uji Prasyarat Pengujian Hipotesis}

a) Hasil uji normalitas sebaran data teknik statistik Kolmogorov-Smirnov (K-S) disajikan dengan rangkuman pada Tabel 4 sebagai berikut:

\begin{tabular}{l|l|c|c|c}
\hline & \multirow{2}{*}{$\begin{array}{c}\text { Model/ } \\
\text { Kelompok }\end{array}$} & \multicolumn{3}{|c}{ Kolmogorov-Smirnov } \\
\cline { 3 - 5 } & \multicolumn{1}{|c|}{ Statistik } & df & Sig. \\
\hline \multirow{2}{*}{ Motivasi } & 1 (Eksperimen) & 0,142 & 22 & $0,200^{*}$ \\
\cline { 2 - 5 } & 2 (Kontrol) & 0,108 & 23 & $0,200^{*}$ \\
\hline \multirow{2}{*}{ HS } & 1 (Eksperimen) & 0,147 & 22 & $0,200^{*}$ \\
\cline { 2 - 5 } & 2 (Kontrol) & 0,116 & 23 & $0,200^{*}$ \\
\hline
\end{tabular}

Dengan taraf signifikansi 5\%, maka hasil perhitungan uji normalitas teknik K-S dinyatakan signifikan jika lebih besar dari 0,05. Karena hasil hitung keempat data >0,05 maka data hasil belajar IPS dan kuesioner motivasi berprestasi pada kelas eksperimen serta kontrol berdistribusi normal.

b) Hasil uji homogenitas varians menggunakan bantuan program SPSS Statistics 17.00 dengan output Levene's Test of Equality of Error Variances yang memuat hasil uji homogenitas varians uji Levene disajikan pada Tabel 5 dan Tabel 6 sebagai berikut.

Tabel 5. Hasil uji homogenitas varians data hasil belajar IPS

\begin{tabular}{c|c|c|c}
\hline F & df1 & df2 & Sig. \\
\hline 0,700 & 1 & 43 & 0,407 \\
\hline
\end{tabular}

Tabel 6. Hasil uji homogentias varians data kuesioner motivasi berprestasi

\begin{tabular}{c|c|c|c}
\hline $\mathbf{F}$ & df1 & df2 & Sig. \\
\hline 0,077 & 1 & 43 & 0,783 \\
\hline
\end{tabular}


Berdasarkan hasil perhitungan uji homogenitas varians dengan output Levene's Test of Equality of Error Variances, signifikansi pada data hasil belajar IPS sebesar 0,407 dan signifikansi pada data kuesioner motivasi berprestasi sebesar 0,783. Dengan taraf signifikansi 5\%, nilai signifikansi kedua data di atas $>0,05$ sehingga kedua data menunjukkan varians yang homogen.

c) Hasil pengujian uji linieritas regresi yang diperhatikan adalah pada bagian Deviation from Linearity. Berikut pada table 7 disajikan rangkuman hasil analisis dengan bantuan program SPSS Statistics 17.00. Hasil uji linieritas regresi dilihat pada bagian Deviation from Liniearity.

\begin{tabular}{l|l|l|c|c|c|c|c}
\hline & & & $\begin{array}{c}\text { Jumlah } \\
\text { Kuadrat }\end{array}$ & df & $\begin{array}{c}\text { Rerata } \\
\text { Kuadrat }\end{array}$ & F & Sig. \\
\hline $\begin{array}{l}\text { Y_Hasil * } \\
\text { X_Motivasi }\end{array}$ & & Kombinasi) & 541,528 & 21 & 25,787 & 4,315 & 0,000 \\
\cline { 3 - 8 } & Linieritas & 465,111 & 1 & 465,111 & 77,829 & 0,000 \\
\cline { 2 - 8 } & & $\begin{array}{l}\text { Simpangan dari } \\
\text { Linieritas }\end{array}$ & 76,417 & 20 & 3,821 & 0,639 & 0,842 \\
\hline & Grup Dalam & 137,450 & 23 & 5,976 & & \\
\cline { 2 - 8 } & Total & 678,978 & 44 & & & \\
\hline
\end{tabular}

Deviation from Liniearity signifikansi bernilai 0,842. Dengan taraf signifikansi 5\% maka signifikansi pada tabel $>0,05$ sehingga data bersifat linier. Selanjutnya, untuk mengetahui keberartian arah regresi, dapat dilihat pada nilai signifikansi bagian Linearity. Apabila nilai signifikansinya lebih kecil dari taraf signifikansi yang ditetapkan $(\alpha=0,05)$, maka koefisien arah regresi berarti atau signifikan. Tabel di atas menunjukan bahwa nilai signifikansi keberartian arah regresi bernilai $<0,001$ atau lebih kecil daripada 0.05. Maka dari itu, dapat disimpulkan bahwa koefisien arah regresi berarti atau signifikan.

\section{Hasil Pengujian Hipotesis}

Pengujian hipotesis penelitian ini dilakukan untuk menguji tiga hipotesis, yaitu uji ANAVA satu jalur untuk hipotesis pertama, uji ANAKOVA satu jalur untuk hipotesis kedua, dan uji korelasi Product-Moment untuk hipotesis ketiga.

a) Pengujian Hipotesis Pertama

\begin{tabular}{c|c|c|c|c|c}
\hline Sumber Varians & JK & db & RJK & F $_{\text {Hitung }}$ & Sig. \\
\hline A_Model & 273,826 & 1 & 273,826 & 29,062 & 0,000 \\
\hline Dalam & 405,152 & 43 & 9,422 & - & - \\
\hline Total & 7135,000 & 45 & - & - & - \\
\hline
\end{tabular}

Untuk mengetahui apakah hipotesis nol ditolak atau diterima pada hipotesis pertama, yang perlu diperhatikan adalah pada harga $F_{\text {hit. }}$ Pada di atas, diketahui bahwa nilai $F_{\text {hit }}=29,062$. Selanjutnya, apabila ditetapkan taraf signifikansi $\alpha=0,05$, maka nilai sig. $(<0,001)$ lebih kecil dari taraf signifikansi $(0,05)$. Maka Ho ditolak dan $\mathrm{H}_{1}$ diterima. Jadi, dapat disimpulkan bahwa terdapat perbedaan yang signifikan hasil belajar IPS antara kelompok siswa yang dibelajarkan dengan model pembelajaran Probing-Prompting dan kelompok siswa yang dibelajarkan dengan model pembelajaran konvensional pada siswa kelas IV di SD Gugus VI Kecamatan Buleleng.

b) Pengujian Hipotesis Kedua

\begin{tabular}{l|c|c|c|c|c}
\hline Sumber Varians & JK & db & RJK & F Hitung & Sig. \\
\hline A_Model & 55,454 & 1 & 55,454 & 14,703 & 0,000 \\
\hline X_Motivasi & 246,740 & 1 & 246,740 & - & - \\
\hline Dalam & 158,412 & 42 & 3,772 & - & - \\
\hline Total & 7135,000 & 45 & - & - & - \\
\hline
\end{tabular}

Untuk mengetahui apakah hipotesis nol ditolak atau diterima pada hipotesis pertama, yang perlu diperhatikan adalah pada harga $F_{\text {hit. }}$ Pada tabel di atas, diketahui bahwa nilai $F_{\text {hit }}=14,703$. Selanjutnya, apabila ditetapkan taraf signifikansi $\alpha=0,05$, maka nilai sig. $(<0,001)$ lebih kecil dari taraf signifikansi $(0,05)$. Maka Ho ditolak dan $\mathrm{H}_{1}$ diterima. Jadi, dapat disimpulkan bahwa terdapat perbedaan yang signifikan hasil belajar IPS antara kelompok siswa yang dibelajarkan dengan model pembelajaran Probing-Prompting dan kelompok siswa yang dibelajarkan dengan model pembelajaran konvensional setelah motivasi berprestasi dikontrol pada siswa kelas IV di SD Gugus VI Kecamatan Buleleng. 


\begin{tabular}{|c|c|c|c|c|c|c|}
\hline & \multirow[t]{2}{*}{ Model } & & & $\begin{array}{c}\text { Koefesien } \\
\text { Standar }\end{array}$ & \multirow[t]{2}{*}{$\mathrm{t}$} & \multirow[t]{2}{*}{ Sig. } \\
\hline & & $\mathrm{B}$ & $\mathrm{SD}$ & Beta & & \\
\hline \multirow[t]{2}{*}{1} & (Konstan) & $-20,682$ & 3,394 & & $-6,094$ & 0,000 \\
\hline & $\begin{array}{l}\text { X_Motivasi } \\
\text { Berprestasi }\end{array}$ & 0,395 & 0,041 & 0,828 & 9,670 & 0,000 \\
\hline
\end{tabular}

Hasil menunjukkan nilai $\mathrm{t}=9,670$ dengan signifikansi $0,000(<0,001)$. Selanjutnya, apabila ditetapkan taraf signifikansi $\alpha=0,05$, maka nilai sig. $(<0,001)$ lebih kecil dari taraf signifikansi $(0,05)$. Maka Ho ditolak dan $\mathrm{H}_{1}$ diterima. Korelasi antara motivasi dan hasil belajar dilihat pada bagian Koefesien Standar Beta, Besarnya korelasi antara motivasi berprestasi dan hasil belajar adalah sebesar 0,828. Jadi, dapat disimpulkan bahwa terdapat korelasi yang signifikan antara motivasi berprestasi dan hasil belajar IPS pada siswa kelas IV di SD Gugus VI Kecamatan Buleleng.

\section{Pembahasan:}

Hasil analisis deskriptif dan analisis statistik pada penelitian ini menunjukkan bahwa skor hasil belajar IPS siswa dengan pembelajaran menggunakan model pembelajaran Probing-Prompting terletak di sekitar rata-rata 14,5 dan simpangan baku (standar deviasi) sebesar 2,54 dan frekuensi ketuntasan berjumlah 13 siswa atau sebesar 59,09\%. Skor hasil belajar IPS yang mengikuti pembelajaran dengan model pembelajaran konvensional terletak di sekitar ratarata 9,61 dan simpangan baku (standar deviasi) sebesar 3,34 dan frekuensi ketuntasan berjumlah 3 siswa atau sebesar $13,04 \%$.

Berdasarkan hasil uji hipotesis yang dilakukan terhadap data yang diperoleh dalam penelitian didapatkan hasil sebagai berikut. Sebelum motivasi berprestasi siswa dikontrol, hasil belajar IPS siswa yang mengikuti pembelajaran dengan model pembelajaran Probing-Prompting lebih baik secara signifikan dibandingkan dengan siswa yang mengikuti pembelajaran dengan model pembelajaran konvensional. Diketahui bahwa nilai $F_{\text {hit }}=29,062$. Selanjutnya, apabila ditetapkan taraf signifikansi $\alpha=0,05$, maka nilai sig. $(<0,001)$ lebih kecil dari taraf signifikansi $(0,05)$.Setelah motivasi berprestasi siswa dikontrol, hasil belajar IPS siswa yang mengikuti pembelajaran dengan model pembelajaran Probing-Prompting lebih baik secara signifikan dibandingkan dengan siswa yang mengikuti pembelajaran dengan model pembelajaran konvensional. Diketahui bahwa nilai $\mathrm{F}_{\text {hit }}=14,703$. Selanjutnya, apabila ditetapkan taraf signifikansi $\alpha=0,05$, maka nilai sig. $(<0,001)$ lebih kecil dari taraf signifikansi $(0,05)$. Adapun besarnya pengaruh model pembelajaran Probing-Prompting sebelum motivasi berprestasi dikontrol adalah sebesar $F_{\text {hit }}=29,062$ dan setelah motivasi berprestasi dikontrol adalah sebesar $\mathrm{F}_{\text {hit }}=14,703$. Hasil perhitungan tersebut menunjukkan tetap terdapat pengaruh model pembelajaran Probing-Prompting, secara kuantitas terjadi penurunan signifikansi antara sebelum motivasi berprestasi dikontrol dengan setelah motivasi berprestasi dikontrol adalah sebesar 14,359.

Kemudian, terdapat korelasi yang signifikan antara motivasi berprestasi siswa dan hasil belajar IPS mendapatkan hasil dengan nilai $\mathrm{t}=9,670$ dengan signifikansi $0,000(<0,001)$. Selanjutnya, apabila ditetapkan taraf signifikansi $\alpha=0,05$, maka nilai sig. $(<0,001)$ lebih kecil dari taraf signifikansi $(0,05)$. Besarnya korelasi antara motivasi berprestasi dan hasil belajar adalah sebesar 0,828 . Hasil pengujian ketiga hipotesis mendapatkan hasil yang signifikan dan $\mathrm{H}_{1}$ diterima pada ketiga hipotesis.

Hasil yang diperoleh menunjukkan bahwa secara keseluruhan dengan tidak mempertimbangkan kovariabel motivasi berprestasi, hasil belajar IPS kelompok siswa yang mengikuti pembelajaran dengan model pembelajaran ProbingPrompting lebih tinggi dibandingkan dengan hasil belajar IPS pada kelompok siswa yang mengikuti pembelajaran dengan model pembelajaran konvensional. Hal itu disebabkan karena pada model pembelajaran konvensional, kegiatan siswa ketika pembelajaran pada bagian guru menyampaikan materi terkesan pasif. Hal ini terlihat dari aktivitas siswa yang duduk diam mendengarkan materi yang disampaikan oleh guru dengan metode ceramah. Kemudian, ketika guru bertanya kepada siswa hanya beberapa siswa yang mengacungkan tangannya. Guru memberikan tugas dalam bentuk diskusi LKS berkelompok, hasil diskusi disampaikan oleh perwakilan kelompok di depan kelas. Berbeda halnya dengan pembelajaran dengan menggunakan model pembelajaran Probing-Prompting, siswa selalu terjaga ketika proses pembelajaran dikarenakan fase-fase dalam model pembelajaran Probing-Prompting membuat siswa antusias. Hal itu ditemukan pada fase keenam, guru yang akan memberikan pertanyaan secara acak kepada siswa lain membuat seluruh siswa bersiap untuk ditunjuk dan menjawab. Temuan-temuan tersebut membuktikan adanya pengaruh yang berbeda dari penggunaan kedua model pembelajaran tersebut.

Selanjutnya, temuan ini memberikan bukti bahwa terdapat pengaruh pembelajaran dengan model pembelajaran Probing-Prompting terhadap hasil belajar IPS pada siswa kelas IV di SD Gugus VI Kecamatan Buleleng. Bukti bahwa model pembelajaran Probing-Prompting sangat efektif adalah karena model pembelajaran Probing-Prompting 
mengkondisikan siswa berada dalam pembelajaran dengan cara guru menyajikan serangkaian pertanyaan yang sifatnya menuntun dan menggali sehingga siswa mengkonstruksi konsep, prinsip, dan aturan menjadi pengetahuan baru.

\section{SIMPULAN DAN SARAN}

Berdasarkan hasil pengujian hipotesis dan pembahasan hasil penelitian, maka simpulan dari penelitian ini adalah sebagai berikut: 1) Terdapat perbedaan yang signifikan hasil belajar IPS antara kelompok siswa yang dibelajarkan dengan model pembelajaran Probing-Prompting dan kelompok siswa yang dibelajarkan dengan model pembelajaran konvensional pada siswa kelas IV di SD Gugus VI Kecamatan Buleleng, dengan hasil $\mathrm{F}_{\text {hit }}=29,062$ dan taraf signifikansi 5\%. 2) Terdapat perbedaan yang signifikan hasil belajar IPS antara kelompok siswa yang dibelajarkan dengan model pembelajaran Probing-Prompting dan kelompok siswa yang dibelajarkan dengan model pembelajaran konvensional setelah motivasi berprestasi dikontrol pada siswa kelas IV di SD Gugus VI Kecamatan Buleleng, dengan hasil $\mathrm{F}_{\text {hit }}=14,703$ dan taraf signifikansi 5\%. 3) Terdapat korelasi yang signifikan antara motivasi berprestasi dan hasil belajar IPS pada siswa kelas IV di SD Gugus VI Kecamatan Buleleng, dengan hasil $t_{h i t}=9,670$ dan korelasi sebesar 0,828 menggunakan taraf signifikansi $5 \%$.

\section{DAFTAR RUJUKAN}

[1] Agung, Gede. 2010. Evaluasi Pendidikan. Singaraja: Jurusan Teknologi Pendidikan, Fakultas Ilmu Pendidikan, Universitas Pendidikan Ganesha.

[2] Candiasa, I Made. 2010a. Statistik Univariat dan Bivariat Disertai Aplikasi SPSS. Singaraja: Unit Universitas Pendidikan Ganesha.

[3] 2010b. Statistik Multivariat Disertai Aplikasi SPSS. Singaraja: Unit Universitas Pendidikan Ganesha.

[4] Lasmawan, Wayan. 2010. Menelisik Pendidikan IPS dalam Perspektif Kontekstual-Empiris. Singaraja: MI Press Bali.

[5] Murda dan Syahrudin. 2000. Buku Ajar Pendidikan Ilmu Pengetahuan Sosial di Sekolah Dasar. Singaraja: Program Studi D2 PGSD IKIP Singaraja.

[6] Shoimin, A. 2014. 68 Model Pembelajaran Inovatif. Yogyakarta: AR-Ruzz Media

[7] Sugiyono. 2010. Metode Penelitian Kuantitatif Kualitatif dan Reseacrh \& Development. Bandung: Alfabeta

[8] Susanto, A. 2013. Teori Belajar dan Pembelajaran di Sekolah Dasar. Jakarta: PT Kharisma Putra Utama.

[9] Suyatno. 2009. Menjelajah Pembelajaran Inovatif. Sidoarjo: Masmedia Buana Pustaka. 